DOI: https://doi.org/10.32839/2304-5809/2020-78.1-6

UDC 81'24=111.374.02

Dyachuk Nataliya

Ivan Franko National University of Lviv,

Agency of Foreign Languages 'RUNA' ${ }^{\circ}$

\title{
LINGUO-DYDACTIC POTENTIAL OF THE APHORISTIC UTTERANCES IN EFL MATERIALS DEVELOPMENT
}

Summary. The best examples of classical and novice aphoristic texts being used in the process of foreign language acquisition with their skillful identification and manipulation definitely promote widening of the linguistic and socio-cultural horizons as well as critical thinking skills of both an EFL learner and a teaching professional. The main aim of the present work we see in singling out and discussing the ways of effective application of imaginative and laconic aphorisms, maxims, proverbs, taglines and catch phrases as a proper authentic material for the creation of activities to master receptive and productive skills, to acquire knowledge in systems (grammar, vocabulary, punctuation), to provide grounds for motivation, culture studies and visual literacy.

Keywords: aphoristic utterances, quotation, authentic material, EFL methodology.

Дячук Н.O.

Львівський національний університет імені Івана Франка; Агенція іноземних мов «РУНА» $®$

\section{ЛІНГВО-ДИДАКТИЧНИЙ ПОТЕНЦІАЛ АФОРИСТИЧНИХ ВИСЛОВЛЮВАНЬ У РОЗРОБЦІ НАВЧАЛЬНИХ МАТЕРІАЛІВ ДЛЯ ВИВЧЕННЯ АНГЛІЙСЬКОІ МОВИ ЯК ІНОЗЕМНОЇ}

Анотація. Використання найкращих зразків класичних та новітніх афористичних текстів у процесі вивчення іноземної мови поряд із умінням їх виділяти та маніпулювати ними безумовно сприяе розширенню лінгвістичних та соціокультурних горизонтів, а також критичного мислення як учня так і профресійного викладача англійської мови як іноземної. Головну мету даної роботи вбачаємо у виділені та обговоренні способів ефективного використання творчих та лаконічних афроризмів, максим, прислів'їв, слоганів до фрільмів та крилатих фрраз у якості автентичного матеріалу для створення завдань 3 метою оволодіння рецептивними та продуктивними мовними навичками, засвоєння знань із системи мови (граматики, словникового запасу, пунктуації), для закладання основ мотивації, вивчення культури та візуальної грамотності.

Ключові слова: афористичні висловлювання, цитати, автентичний матеріал, методика викладання англійської мови як іноземної.

Droblem statement. "What any person in the world can learn, almost all persons can learn if provided with appropriate prior and current conditions of learning", - wrote B. Bloom. Recently his famous taxonomy has undergone evolutionary changes. L. Anderson and D. Krathwohl [25] substituted the top of the pyramid, which used to be dealing with judging the value of information or ideas, by creativity, which in its way encompasses mental processes of combining parts to make a new whole. EFL practitioners handle materials for language learning through their evaluation, adaptation, design, production, exploitation and research. Sometimes educators face the challenge of being creative and find it difficult to get oriented in the ample selection of ready-made resources. On the other hand, many are unaware of the authentic materials worth utilizing for numerous topical areas of modern language curriculum as well as resources to boost creativity in students.

Famous quotes from literature, history, movies, media, arts and entertainment vehicles resonate with many people. Getting to know the best examples of classical and novice aphoristic texts in the process of foreign language acquisition, and teaching how to be skillful in identification, use and manipulation with them, definitely promote widening of the linguistic and socio-cultural horizons as well as critical thinking skills of a future EFL professional.
Recent research and publications. D. Crystal in "The Cambridge Encyclopedia of the English Language" writes: "Anything which someone has said or written can be a quotation, but the term usually refers to those instances which have become famous over the years" [8, p. 184]. Scientists name these types of sayings using a great variety of terms: adage, apothegms, axiom, epigram, maxim, proverb, truism, percept, and dictum. The most popular quotations are generally aphorisms, because they are short and concise, and therefore easy to remember and share. Aphorists often employ striking metaphors that give their sayings even more staying power. This idea is remarkably close to S.T. Coleridge's assertion that "the largest and worthiest portion of our knowledge consists of aphorisms".

B. Tomlinson in his work "Materials Development for Language Learning and Teaching" [25] highlights the functions of educational materials as informative, instructional, experiential, eliciting, and exploratory. As different learners learn in a variety of ways aphoristic quotations become the ideal educational resource materials with their aim being to provide a range of language acquisition means for the learners to experience and select from. Thus, language learners are to be prepared to demonstrate their reaction to mental and linguistic stimuli an aphoristic quotation makes in various forms of communicative interaction utilizing all language skills. 
The illustrative material we recommend to utilize for practical assignments could be made on the basis of selected and systematized groups of aphoristic utterances in the collections by M. Grothe [14; 15; 16], O. Wilde [11], J. Lloyd et al. [17], as well as examples taken from the books by L.M. Medvedyeva [18], J.M. Demakis [10], N.O. Diachuk [9], O. Grabovetska [28], J.M. Shanahan [22].

The purpose of the article. The study represents an attempt to enumerate the learning objectives of incorporating aphoristic quotations into the EFL study, to examine and systematize common and unconventional sources of such statements and, finally, to focus on practical suggestions of their application at the lessons for those majoring in English.

Presentation of the main material. The learning objectives to use aphoristic quotations in class to inspire, encourage, increase motivation and develop high-level thinking skills may include the following: to evaluate the validity of thought behind quotations; to analyze quotations using critical thinking techniques; to compare and contrast multiple quotations; to classify quotations by application; to apply quotations to a variety of content areas; to spot and represent quotations with a variety of media, print and visual texts.

Where to find a quotation for one's teaching? The supplies may be numerous, ranging from wellknown dictionaries of quotations or proverbs, literature, cinema scripts, TV programmes, songs, internet resources to your own students'essays or colleagues'sayings. In Table 1 we succeeded to enumerate 39 sources rich in aphoristic sayings, and further supplied illustrative examples.

A good aphorism can really stick in the mind. The best aphorisms are also applicable to all sorts of different situations, which further add to their

Conventional and Unconventional Places to Look for Aphoristic Utterances

Table 1

Printed resources

\section{Literature}

Fiction (classical \& modern)

educational literature

(manuals \& textbooks)

poetry

dictionaries /encyclopedia of quotations \& aphorisms

\section{Examples}

We live in the age that reads too much to be wise and thinks too much to be beautiful (Oscar Wilde) [11; p.61]

Life is a foreign language: all men mispronounce it (Christopher Morley); Cruelty and benevolence are but the shades of the same colour (Khaled Hosseini) [10, p. 14]; Chance makes the thief (Donna Tartt) [24, p. 632]

(Грабовецька О.C., 2014).[28]

(Diachuk N., 2002) [9]

(Medvedeva L.M., 1990) [18]

poem 'Life' by Mother Teresa [4, p. 48]

Stop all the clocks, cut off the telephone (W. H.Auden) [1, p. 49]

What you get free costs too much (Jean Anouiln) [13]

Laughter is tranquilizer with no side effects [12]

If you don't think too good, don't think too much (T. Williams) [14]

\begin{tabular}{|c|}
\hline Folklore \\
\hline proverbs \\
\hline Religion \\
\hline religious literature \\
Bible, Koran, \\
Bhagavat Gita
\end{tabular}

A man without a smiling face should not open a shop (Chinese proverb)

\section{Video resources}

\begin{tabular}{|c|c|}
\hline feature films & $\begin{array}{l}\text { Reellifewisdom.com } \\
\text { Subzin.com } \\
\text { IMDb.com } \\
\text { Years, lovers and glasses of wine - these are things that should never be counted } \\
\text { ("The Age of Adaline", 2015) } \\
\text { (J. Scheibli) [23] }\end{array}$ \\
\hline taglines & Life is waiting ("Terminal", 2004) \\
\hline speech of the characters & $\begin{array}{l}\text { You want something done, do it yourself! (Zorg, "The } 5^{\text {th }} \text { Element", 1997); No matter } \\
\text { what anybody, tells you, words and ideas can change the world (Keating, "Dead } \\
\text { Poets' Society", 1989) }\end{array}$ \\
\hline TED presentations & $\begin{array}{l}\text { People believe what they want to believe (K. Schulz "On Being Wrong"); Own your } \\
\text { own success (Sh. Sandberg "Why we have too few women leaders?") }\end{array}$ \\
\hline documentaries & $\begin{array}{l}\text { Even while Rome is burning there's somehow time for shopping at IKEA } \\
\text { ('Minimalism' Catelyst SPYA, 2015) }\end{array}$ \\
\hline animated cartoons & $\begin{array}{l}\text { Let's do what we do best, Scoob, eat (Scooby Do) } \\
\text { People talk loud when they want to sound smart, right? (Sponge Bob Square Pants) }\end{array}$ \\
\hline \multicolumn{2}{|l|}{ Printed Media } \\
\hline newspaper articles & $\begin{array}{l}\text { Before you judge someone, walk a mile in their shoes. If you really want to understand } \\
\text { someone, you eat what they eat ("Can I look like Emmanuel Macron?" by Stephen } \\
\text { Bush, "The Guardian, No.56, January 2018) }\end{array}$ \\
\hline magazine articles & $\begin{array}{l}\text { Learn character from trees, values from roots and change from leaves ("How trees } \\
\text { talk to each other?" by Neelima Choahan, The Press) }\end{array}$ \\
\hline
\end{tabular}

How long you men turn my glory into shame? How long will you love delusions seek false gods? (Psalms4:2)

A house divided against itself cannot stand (Mathew 12:25, The Holy Bible) (Piper R.A., 1989) [21] 
(Continuation of table 1)

\section{Printed resources}

advertisements

\section{Examples}

Find someone who will ruin your lipstick not your mascara (Benefit Cosmetics, $\mathrm{UN})$; It takes many to save one (Doctors without borders campaign)

\begin{tabular}{|c|c|}
\hline \multicolumn{2}{|l|}{ Visual Media } \\
\hline TV programmes & $\begin{array}{l}\text { Sometimes you cannot see yourself clearly until you see yourself through the eyes of } \\
\text { others ("The Ellen DeGeneres Show") }\end{array}$ \\
\hline advertising slogans & $\begin{array}{l}\text { Good things come to those who wait (Guinness slogan) } \\
\text { Every little helps (the TESCO ads) }\end{array}$ \\
\hline podcasts & $\begin{array}{l}\text { You may desire more even though you are afraid of letting yourself have it (S. Lackmann } \\
\text { "5 Reasons People Choose to Stay Single". Psychology Today, Oct. 24, 2016) }\end{array}$ \\
\hline \multicolumn{2}{|r|}{ (2: } \\
\hline Facebook & If you can't say it to their face, don't post it (Audrie Peterson) [27] \\
\hline Pinterest & https://www.pinterest.com/TransAbroad/quotes-and-aphorisms/?lp=true \\
\hline Instagram & $\begin{array}{l}\text { \#aphorisms; \#aphorismsonloveandhate; } \\
\text { \#aphorismsandquotes; \#aphorismsandsayings } \\
\text { With great eyebrows come great responsibility (Instagram post by Benefit Cosmetics, US) }\end{array}$ \\
\hline Twitter & $\begin{array}{l}\text { A Twitter hashtag (\#quotes) used to share quotes } \\
\text { Customers don't expect you to be perfect. They DO expect you to fix things when they } \\
\text { go wrong (Twitter message from Donald Porter, V.P. of British Airways) }\end{array}$ \\
\hline Padlet & Padlet.com - a virtual blank wall to post on \\
\hline \multicolumn{2}{|l|}{ Music world } \\
\hline songs & $\begin{array}{l}\text { The show must go on (Queen) } \\
\text { You got to cry without weeping } \\
\text { Talk without speaking } \\
\text { Scream without raising your voice } \\
\text { (U2 Running to stand Still, The Joshua Tree) }\end{array}$ \\
\hline \multicolumn{2}{|l|}{ Personal sayings } \\
\hline $\begin{array}{l}\text { famous people or moral } \\
\text { authorities }\end{array}$ & $\begin{array}{l}\text { Failure is only the opportunity to begin again more intelligently (Henry Ford) } \\
\text { You must be the change you want to see in the world. (Mahatma Gandhi) }\end{array}$ \\
\hline philosophers & $\begin{array}{l}\text { We are what we repeatedly do. } \\
\text { Excellence then, is not a single act, but a habit. (Aristotle) }\end{array}$ \\
\hline politicians & Do not pray for easy lives... Pray to be stronger men (John F. Kennedy) \\
\hline psychologists & $\begin{array}{l}\text { My ambition is to say in ten sentences what everyone else says in a book (Friedrich } \\
\text { Nietzsche) }\end{array}$ \\
\hline educators & $\begin{array}{l}\text { If you're not prepared to be wrong, you'll never come up with anything original (Sir } \\
\text { Ken Robinson) }\end{array}$ \\
\hline scientists & Only a life lived in the service to others is worth living (Albert Einstein) \\
\hline celebrities & $\begin{array}{l}\text { Elegance is the only beauty that never fades } \\
\text { (Audrey Hepburn) [1, p. 858] }\end{array}$ \\
\hline personal letters/diaries & $\begin{array}{l}\text { Live fast, die young, and leave a good-looking corpse (Irene L.Luse in her letter to } \\
\text { Oscar B.Luce) [1, p. 46] }\end{array}$ \\
\hline \multicolumn{2}{|l|}{ WWW resources } \\
\hline $\begin{array}{l}\text { web pages with collections of } \\
\text { sayings and aphorisms }\end{array}$ & $\begin{array}{l}\text { Quotabl.es } \\
\text { Numberquotes.com } \\
\text { Quotecoil.com } \\
\text { Brainyquote.com } \\
\text { http://www.rdcopperr.us/33-perfect-aphorism-quotes/ } \\
\text { https://quote-citation.com/en/aphorism }\end{array}$ \\
\hline $\begin{array}{l}\text { methodological resources for } \\
\text { EFL teachers }\end{array}$ & $\begin{array}{l}\text { http://onestopteachershop.com/2014/03/using-quotes-in-classroom.html } \\
\text { https://the-teacher-next-door.com/my-blog/classroom-ideas/5-ways-to-use- } \\
\text { quotations-in-the-classroom }\end{array}$ \\
\hline blogs & Quotation Weblog \\
\hline quotes of the day & Quotesecret.com \\
\hline \multicolumn{2}{|l|}{ Visual Art } \\
\hline \multicolumn{2}{|l|}{ painting of definite artists } \\
\hline $\begin{array}{l}\text { Yevgeniya Gapshynska } \\
\text { (Ukraine) }\end{array}$ & Sometimes we just need to take some time for ourselves \\
\hline $\begin{array}{c}\text { Berni Parker } \\
\text { (the United Kingdom) }\end{array}$ & If you have crazy friends you have everything \\
\hline comics by Hank Ketcham & $\begin{array}{l}\text { No job is satisfying if you do it halfheartedly. } \\
\text { ("Dennis the Menace" cartoon) }\end{array}$ \\
\hline doodle art & Bit.ly/quotedoodle \\
\hline \multicolumn{2}{|l|}{ Body art } \\
\hline tatoos & Do what you want; Inhale confidence, exhale doubt \\
\hline
\end{tabular}


(End of table 1)

Printed resources

\begin{tabular}{|c|c|}
\hline \multirow{2}{*}{\multicolumn{2}{|c|}{ Street art }} \\
\hline & \\
\hline graffiti & Some people are so poor, all they have is money \\
\hline wall art decor & $\begin{array}{l}\text { Life Is Like Riding a Bicycle, To Keep Your Balance You Must Keep Moving (Albert } \\
\text { Einstein, Inspirational Motto Canvas Print) }\end{array}$ \\
\hline \multicolumn{2}{|r|}{ (2: } \\
\hline $\begin{array}{l}\text { chewing gum 'Love is' inserts } \\
\text { - comics by Kim Casalli }\end{array}$ & $\begin{array}{l}\text { Love is what helps you take everything life throws at you (https://www.google.com/ } \\
\text { search?q=love+is+chewing+gum+quotes) } \\
\text { Love Is...being able to say you are sorry. } \\
\text { Love Is...being able to say you are sorry. (https://en.wikipedia.org/wiki/Love_Is...) }\end{array}$ \\
\hline $\begin{array}{l}\text { Chinese cookies with } \\
\text { prophesies }\end{array}$ & Failure is not falling down but refusing to get up (Chinese proverb) \\
\hline \multicolumn{2}{|l|}{ Clothes } \\
\hline T-shirts & Most people only dream of meeting their heroes. I teach mine \\
\hline \multicolumn{2}{|l|}{ Educational setting } \\
\hline teacher's expressions & $\begin{array}{l}\text { When little people are overwhelmed by big emotions, it's our job to share our calm } \\
\text { and not to join their chaos. (I.R.Knost) rdcopperr.us/35-awesome-inspirational- } \\
\text { quotes-for-kids-from-teachers/ } \\
\text { The day you are willing to veer off the lesson, follow the kids's lead and learn with } \\
\text { your students is the day you really become a teacher (www.venspired.com) }\end{array}$ \\
\hline $\begin{array}{l}\text { students' expressions and } \\
\text { writing }\end{array}$ & I try not to laugh at my jokes, but we all know I am hilarious (www.sarcasticMe.com) \\
\hline $\begin{array}{l}\text { maxims of the English } \\
\text { language teaching, } \\
\text { by B. Barne }\end{array}$ & $\begin{array}{c}\text { A bad teacher blames the students. A wise teacher blames the previous teacher; } \\
\text { Whatever interests the teacher will bore the students and vice versa) [2] }\end{array}$ \\
\hline
\end{tabular}

memorable quality. H.E. Gardner sees the task for the new millennium not in sharpening various intelligences and using them. On the contrary, he asserts that "we must figure out how intelligence and morality can work together to create a world in which a great variety of people will want to leave" [19, p. 4]. "In order to accomplish being integral and becoming more whole and fully integrated, we need to carefully examine what we hold most dear, and name those things we value above all others. In naming and defining these precious things, we need to be truthful - for these are our muses, our sources of inspiration and renewal" [6]. Due to M.Clifford "we may have stumbled upon our muses accidentally, or through intentional or very deliberate processes or through the natural process of maturation. Searching for ones muses is part of ones life script". Teachers are prone to become fellow travellers too, the ones who are looking, but who are willing to share parts of their discoveries.

Referring to aphoristic utterances as a building material for classroom assignments design it is worth considering divergent and convergent types of thinking models. Standardized tests do a great job of measuring convergent thinking that includes analytical thinking or logical answers with one correct response. Divergent thinking considers how a learner can use different ways to approach a problem. It requires using association and multiplicity of thought [6]. This can eventually cause a multidimensional approach to processing a given set of aphoristic statements and their classroom use.

We propose the systematized the list of EFL educational areas where aphoristic statements fit best for classroom application in Table 2 .

The ability to react to a quotation by explaining what it means, taking a stand on it, showing its relevance and connection to other aspects of life and art represent a practical skill that is on demand in a variety of language tests in different subject areas.
Assumptions to have in order to enliven a class: 1) aphoristic quotations may be used as a class décor and turned into 'call backs', that is phrases repeated or read with definite interval; 2) carefully selected quotes bring inspiration to our daily lives and provide teachers with meaningful, cross-curricular activities; 3) any social media (Facebook, Pinterest, Instagram, Twitter) previously thought as throw-away bits of media now are hugely popular in hooking attention of present-day digital generation with inspirational quotes and funny memes; 4) the quotes that emphasize important life lessons teachers want their students to leave their classroom with should be provided; 5) we propose a list of arguments to be considered by an educator in favour of application of aphoristic utterances for materials development.

Assumptions to have in order to foster learning: 1) a good quote is usually associated with a definite period in time, a perfect quote can define a historical period as nothing else can - using quotes to help teach any subject is a good tool to aid students' learning, e.g., historical quotes [17] stimulate debate, develop critical thinking skills and encourage learning outside of the classroom; 2) some quotes are great for quick and easy modeling of analysis, this may mean describing how the quote might apply to literature, popular culture, current events, history or the speaker's own life experience; 3) the question 'who said the quote?' will lead to internet search and provide background for interest in new people and opinions - works by A.C. Brown [3], N. Chokshi [5] and G. O'Toole [19] can be recommended in this respect; 4) a selection of quotes by a single author may urge students to guess his/her lifestyle, personality, literary works, morals and traditions of the epoch he/she lived in [1], what is more, comparing and contrasting two different quotes by the same person is a great way to look at change. 
Areas of an Aphoristic Utterance Application in EFL Classroom

Table 2

\begin{tabular}{|c|c|c|}
\hline Classroom management & Skills development & Systems development \\
\hline Lesson planning stages & Receptive skills & Grammar \\
\hline \multirow{2}{*}{$\begin{array}{l}\text { Lesson/ topic lead-in; } \\
\text { gist task; } \\
\text { detailed tasks based on } \\
\text { comprehension questions; } \\
\text { follow-up tasks; } \\
\text { matching quotes to the curriculum; } \\
\text { compiling lists of top 5-20 best } \\
\text { aphoristic quotes; } \\
\text { quotes used as classroom decoration; } \\
\text { quote corner/board; } \\
\text { material for pair and group work } \\
\text { (WebQuests, hometasks) }\end{array}$} & $\begin{array}{l}\quad \text { Reading } \\
\text { recognizing links between ideas; } \\
\text { using context to predict content; } \\
\text { ability to understand intended } \\
\text { double or inferred meaning of a } \\
\text { written text }\end{array}$ & \multirow{2}{*}{$\begin{array}{l}\text { recognizing and understanding } \\
\text { grammar; } \\
\text { illustrating various sentence types } \\
\text { and structures; } \\
\text { identifying referencing, substitution, } \\
\text { ellipsis; } \\
\text { making transformations while } \\
\text { changing the statement from direct } \\
\text { to indirect speech; } \\
\text { dictation; } \\
\text { sentence cloze, gap-filling and multiple } \\
\text { choice activities based on quotes }\end{array}$} \\
\hline & $\begin{array}{l}\text { • Listening } \\
\text { recognizing word boundaries; } \\
\text { recognizing links between words; } \\
\text { ability to catch punch line, follow } \\
\text { extended speech on abstract and } \\
\text { complex topics }\end{array}$ & \\
\hline Motivation & Productive skills & \\
\hline $\begin{array}{l}\text { set learning objectives; } \\
\text { reflection on pace of studies; } \\
\text { matching quotes to current events in } \\
\text { personal and societal life; } \\
\text { matching quotations to definite } \\
\text { people/celebrity due to background } \\
\text { knowledge as to what might be said } \\
\text { and why }\end{array}$ & $\begin{array}{l}\quad \text { Speaking } \\
\text { developing public speaking skills; } \\
\text { making well-structured and detailed } \\
\text { presentations on a wide range of topics; } \\
\text { using logical stress to help } \\
\text { understand a message; } \\
\text { apply various intonation patterns; } \\
\text { making arguments and justifying } \\
\text { them with a quote; } \\
\text { conveying finer shades of meaning } \\
\text { by using a wide range of modification } \\
\text { devices }\end{array}$ & $\begin{array}{l}\text { pre-teaching of vocabulary; } \\
\text { matching word and definition with } \\
\text { special attention to abstract notions; } \\
\text { redefinition of a term in aphoristic } \\
\text { way; } \\
\text { creating message a certain tone due } \\
\text { to elaborate vocabulary selection; } \\
\text { recognizing the tone of the message; } \\
\text { using 'quote of the day' with topical } \\
\text { words of the day activities; } \\
\text { ranking quotes due to the degree of a } \\
\text { certain quality expressed }\end{array}$ \\
\hline Culture studies & \multirow{2}{*}{$\begin{array}{l}\text { • Writing } \\
\text { adapting a quote into one's writing; } \\
\text { developing skills and ability } \\
\text { paraphrase; } \\
\text { avoiding plagiarism; } \\
\text { creating message a certain tone }\end{array}$} & Punctuation \\
\hline $\begin{array}{l}\text { ability to infer cultural context from } \\
\text { a quote; } \\
\text { learning to spot cultural bias and } \\
\text { stereotypes; } \\
\text { recognizing cultural and societal } \\
\text { values }\end{array}$ & & $\begin{array}{l}\text { mastering punctuation; } \\
\text { changing the punctuation with an } \\
\text { intention to change meaning of a } \\
\text { phrase; } \\
\text { changing the syntax of a quote to } \\
\text { match the way somebody would say }\end{array}$ \\
\hline Visual literacy & Reflection on skills & Critical thinking skills \\
\hline $\begin{array}{l}\text { ability to decode meaning of an } \\
\text { image connected with a text; } \\
\text { making inspirational posters; } \\
\text { drawing pictures to depict meaning } \\
\text { of a quote }\end{array}$ & $\begin{array}{l}\text { making a clear strong argument } \\
\text { during discussion; } \\
\text { information processing, analysis and } \\
\text { summarizing }\end{array}$ & $\begin{array}{l}\text { making inferences; } \\
\text { expressing attitude; } \\
\text { comparing and contrasting notions, } \\
\text { logical linking }\end{array}$ \\
\hline
\end{tabular}

Assumptions to enable students apply what was learned: 1) all students at some point will have to use borrowed material in their writing, while there are three ways to use borrowed material via quoting, summarizing and paraphrasing, students often use direct quotes to support their assertions, in order to integrate a quote smoothly and make clear how the quote functions to support one's assertions S. Cook [7; p. 3] proposes to use 'a quote sandwich' principle (introduction-quote-follow up); 2) teaching the ways of introducing a quote, punctuating quoted material, using various quote templates in academic writing would be of great use as well as developing an ability to recognize and repair common errors in incorporating quotations; 3) grammar issues such as sentence transformation, reported speech, use of tenses, translation and summarizing could easily be practiced with quotations; 4) any quote may be utilized as a writing prompt, the focus of a personal experiential essay, essay preface, topic of a project or public speech.

Conclusion. To summarize the results of our research, we may say that a delightful collection of aphoristic utterances, which may lay the basis of numerous tasks offers both teachers and learners a wealth of linguistic and cultural information to be relied on in the process of mastering language skills - authentic, non-trivial, and, thus, motivating. Using aphoristic quotes in any classroom gets students to make connections to the learning that goes on outside its boundaries. Let us encourage teachers to be creative in practical application of aphorisms, because we will never know how those quotes will resonate and inspire our students' lives and learning.

\section{References:}

1. Arp, R.; Rees, N. (2016). 1001 Quotations to Inspire You Before You Die. Cassel Illustrated. Quintessence Editions Ltd. $960 \mathrm{p}$.

2. Barne, S. (2003). Bystander. IATEFL ISSUES. August-September.

3. Brown, A.C.; Schulten, K. (2010). An American Wit: Approaching mark Twain's Life and Works. Available from: https://learning.blogs.nytimes.com/2010/09/30/a-american-wit-approaching-mark-twains-life-and-works/

4. Ceban, G. (2003). The Passion for Life. English Teaching Forum. July. P. 48.

5. Chokshi, N. (2017). Can you guess who said these common quotations? NY Times. Apr. 28. Available from: https://www.nytimes.com/interactive/2017/04/28/books/who-said-it-quotation-quiz.html 
6. Clifford, M. (2012). 30 Things You Can do to Promote Creativity. InformED. Available from: https://www. opencolleges.edu.au/informed/features/30-things-you-can-do-to-promote-creativity-in-your-classroom/

7. Cook, S. Lesson Plan: Incorporating Quotations. Available from: http://www.sjsu.edu/aanapisi/docs/saracooklessonplan.pdf

8. Crystal, D. (1995). The Cambridge Encyclopedia of the English Language. Cambridge, 490 p.

9. Diachuk, N. (2002). Picture the World. Lviv: Apriori, $180 \mathrm{~s}$.

10. Demakis, J.M. (2012). The Ultimate Book of Quotations. Paperback. Nov. 19.

11. Epigrams of Oscar Wilde (2007). Wordsworth Reference Series. 240 p.

12. Gardner, H.E. (2000). Intelligence Reframed: Multiple Intelligences for the 21st Century. Basic Books. 304 p.

13. Geary, J. (2002). Who is the author of the New York Times Best-Selling The World in a Phrase: A Brief History of the Aphorism and Geary's Guide to the World's Great Aphorists. Available from: https://jamesgeary.com/

14. Grothe, M. (2004). Oxymoronica. Paradoxical Wit and Wisdon from History's Greatest Wordsmiths. Collons Reference. $246 \mathrm{p}$

15. Grothe, M. (2008). I Never metaphor I didn't Like. A Comprehensive Compilation of History's Greatest Analogies, Metaphors, and Similes. Collons Reference. 330 p.

16. Grothe, M. (2009). Ifferisms. An Anthology of Aphorisms that Begin with the Word IF. Collons Reference. $326 \mathrm{p}$.

17. Lloyd, J., Mitchinson, J., Harkin, J. (2015). 1,234 QI Facts to Leave You Speechless. Faber\&Faber. 338 p.

18. Medvedeva, L.M. (1990). English Grammar in Proverbs, Sayings, Idioms and Quotations. Kyiv: Izd. pri Kievskom universitete, $240 \mathrm{~s}$.

19. O'Toole, G. Hemingway Didn't Say That: The Truth Behind Familiar Quotations. Kindle Ed. Available from: https://www.amazon.com/Hemingway-Didnt-Say-That-Quotations-ebook/dp/B01K4TXVWA/

20. Piper, R.A. (1989). Wisdom in the Q-Tradition: The Aphoristic Teaching of Jesus. Cambridge University Press. 336 p.

21. Shanahan, J.M. (2005). Most Brilliant Thoughts of All Time (in two lines or less). WILLIAM MORROW an Imprint of HarperCollins Publishers. $324 \mathrm{p}$.

22. Scheibli, J. Movie Quotes for All Occasions: Unforgettable Lines for Life's Biggest Moments. Available from: https://www.amazon.com/dp/B06Y3TB8VC/ref=sspa_dk_detail_0?psc=1

23. Tartt, D. (2013). The Goldfinch. ABACUS. 866 p.

24. Tomlinson, B. (2001). Materials Development for Language Learning and Teaching. Cambridge: Cambridge University Press.

25. Wilson, L.O. (2016). Anderson and Krathwohl - Bloom's Taxonomy Revised. Understanding the New Version of Bloom's Taxonomy. Available from: https://thesecondprinciple.com/teaching-essentials/beyond-bloom-cognitivetaxonomy-revised/

26. Luxurius Facebook Drama Quotes (2018). Mar. 7. Blog. Available from: http://www.rdcopperr.us/27-luxuriusfacebook-drama-quotes/

27. Grabovetska O.S. (2014). Praktykum z lingvostylistuchnogo ta perekladoznavchogo analizy (na materiali pyesy Oskara Yalda "The Importance of Being Earnest" ta ii ukrainskogo pereklady [Practice of linguostylistic and translation studies analysis (on the basis of the play by Oscar Wilde "The Importance of Being Earnest" and its translation into Ukrainian]. Lviv: LNU im. I. Franka, 144 p.

\section{Список літератури:}

1. Arp, R.; Rees, N. (2016). 1001 Quotations to Inspire You Before You Die. Cassel Illustrated. Quintessence Editions Ltd. $960 \mathrm{p}$.

2. Barne, S. (2003). Bystander. IATEFL ISSUES. August-September.

3. Brown, A.C., Schulten, K. (2010). An American Wit: Approaching mark Twain's Life and Works. Available from: https://learning.blogs.nytimes.com/2010/09/30/a-american-wit-approaching-mark-twains-life-and-works/

4. Ceban, G. (2003). The Passion for Life. English Teaching Forum. July. P. 48.

5. Chokshi, N. (2017). Can you guess who said these common quotations? NY Times. Apr. 28. Available from: https://www.nytimes.com/interactive/2017/04/28/books/who-said-it-quotation-quiz.html

6. Clifford, M. (2012). 30 Things You Can do to Promote Creativity. InformED. Available from: https://www.opencolleges.edu.au/informed/features/30-things-you-can-do-to-promote-creativity-in-your-classroom/

7. Cook, S. Lesson Plan: Incorporating Quotations. Available from: http://www.sjsu.edu/aanapisi/docs/saracooklessonplan.pdf

8. Crystal, D. (1995). The Cambridge Encyclopedia of the English Language. Cambridge. 490 p.

9. Diachuk, N. (2002). Picture the World. Львів : Апріopi, 180 c.

10. Demakis, J.M. (2012). The Ultimate Book of Quotations. Paperback. Nov. 19.

11. Epigrams of Oscar Wilde (2007). Wordsworth Reference Series. 240 p.

12. Gardner, H.E. (2000). Intelligence Reframed: Multiple Intelligences for the 21st Century. Basic Books. 304 p.

13. Geary, J. (2002). Who is the author of the New York Times Best-Selling The World in a Phrase: A Brief History of the Aphorism and Geary's Guide to the World's Great Aphorists. [Electronic resource]. Available from: https://jamesgeary.com/

14. Grothe, M. (2004). Oxymoronica. Paradoxical Wit and Wisdon from History's Greatest Wordsmiths. Collons Reference. $246 \mathrm{p}$.

15. Grothe, M. (2008). I Never metaphor I didn't Like. A Comprehensive Compilation of History's Greatest Analogies, Metaphors, and Similes. Collons Reference. $330 \mathrm{p}$.

16. Grothe, M. (2009). Ifferisms. An Anthology of Aphorisms that Begin with the Word IF. Collons Reference. $326 \mathrm{p}$.

17. Lloyd, J., Mitchinson, J., Harkin, J. (2015). 1,234 QI Facts to Leave You Speechless. Faber\&Faber. 338 p.

18. Medvedeva, L.M. English Grammar in Proverbs, Sayings, Idioms and Quotations. Киев : Изд-во при Киевском университете, 1990. 240 c.

19. O’Toole, G. Hemingway Didn't Say That: The Truth Behind Familiar Quotations. Kindle Ed. Available from: https://www.amazon.com/Hemingway-Didnt-Say-That-Quotations-ebook/dp/B01K4TXVWA/

20. Piper, R.A. (1989). Wisdom in the Q-Tradition: The Aphoristic Teaching of Jesus. Cambridge University Press. $336 \mathrm{p}$.

21. Shanahan, J.M. (2005). Most Brilliant Thoughts of All Time (in two lines or less). WILLIAM MORROW an Imprint of HarperCollins Publishers. 324 p. 
22. Scheibli, J. Movie Quotes for All Occasions: Unforgettable Lines for Life's Biggest Moments. Available from: https://www.amazon.com/dp/B06Y3TB8VC/ref=sspa_dk_detail_0?psc=1

23. Tartt, D. (2013). The Goldfinch. ABACUS. 866 p.

24. Tomlinson, B. (2001). Materials Development for Language Learning and Teaching. Cambridge: Cambridge University Press.

25. Wilson, L.O. (2016). Anderson and Krathwohl - Bloom's Taxonomy Revised. Understanding the New Version of Bloom's Taxonomy. Available from: https://thesecondprinciple.com/teaching-essentials/beyond-bloom-cognitivetaxonomy-revised/

26. Luxurius Facebook Drama Quotes. (2018) Mar. 7. Blog. Available from: http://www.rdcopperr.us/27-luxuriusfacebook-drama-quotes/

27. Грабовецька О.С. Практикум з лінгвостилістичного та перекладознавчого аналізу (на матеріалі п’еси Оскара Вайлда «The Importance of Being Earnest» та її українського перекладу). Львів : ЛНУ ім. Івана Франка, 2014. 144 с. 